Article

\title{
Elucidation of Antimicrobial Silver Sulfadiazine (SSD) Blend/Poly(3-Hydroxybutyrate-co-4-Hydroxybutyrate) Immobilised with Collagen Peptide as Potential Biomaterial
}

\author{
Sevakumaran Vigneswari ${ }^{1}$, Tana Poorani Gurusamy ${ }^{2}$, H. P. S. Abdul Khalil ${ }^{3}{ }^{(D)}$, \\ Seeram Ramakrishna ${ }^{4}$ (D) and Al-Ashraf Abdullah Amirul 2,5,6,*(D) \\ 1 Faculty of Science and Marine Environment, Universiti Malaysia Terengganu, Kuala Nerus 21030, \\ Terengganu, Malaysia; vicky@umt.edu.my \\ 2 School of Biological Sciences, Universiti Sains Malaysia, Penang 11800, Malaysia; purani_guru@yahoo.com \\ 3 School of Industrial Technology, Universiti Sains Malaysia, Penang 11800, Malaysia; akhalilhps@gmail.com \\ 4 Center for Nanofibers and Nanotechnology, Department of Mechanical Engineering, National University of \\ Singapore, Singapore 117581, Singapore; seeram@nus.edu.sg \\ 5 Centre for Chemical Biology, Universiti Sains Malaysia, Bayan Lepas, Penang 11900, Malaysia \\ 6 Malaysian Institute of Pharmaceuticals and Nutraceuticals, NIBM, Penang 11700, Malaysia \\ * Correspondence: amirul@usm.my
}

Received: 2 November 2020; Accepted: 10 December 2020; Published: 14 December 2020

\begin{abstract}
The quest for a suitable biomaterial for medical application and tissue regeneration has resulted in the extensive research of surface functionalization of material. Poly(3-hydroxybutyrate-co-4hydroxybutyrate) $[\mathrm{P}(3 \mathrm{HB}-c o-4 \mathrm{HB})]$ is a bacterial polymer well-known for its high levels of biocompatibility non-genotoxicity, and minimal tissue response. We have designed a porous antimicrobial silver SSD blend/poly(3HB-co-4HB)-collagen peptide scaffold using a combination of simple techniques to develop a scaffold with an inter-connected microporous pore in this study. The collagen peptide was immobilised via $-\mathrm{NH}_{2}$ group via aminolysis. In order to improve the antimicrobial performance of the scaffold, silver sulfadiazine (SSD) was impregnated in the scaffolds. To confirm the immobilised collagen peptide and SSD, the scaffold was characterized using FTIR. Herein, based on the cell proliferation assay of the L929 fibroblast cells, enhanced bioactivity of the scaffold with improved wettability facilitated increased cell proliferation. The antimicrobial activity of the SSD blend/P(3HB-co-4HB)-collagen peptide in reference to the pathogenic Gram-negative, Gram-positive bacteria and yeast Candida albicans exhibited SSD blend/poly(3HB-co-4HB)-12.5 wt $\%$ collagen peptide as significant construct of biocompatible antibacterial biomaterials. Thus, SSD blend/P(3HB-co-4HB)-collagen peptide scaffold from this finding has high potential to be further developed as biomaterial.
\end{abstract}

Keywords: poly(3-hydroxybutyrate-co-4-hydroxybutyrate); collagen peptide; aminolysis; surface functionalization

\section{Introduction}

Biomaterials serve as an interface with the biological systems to evaluate, augment, treat, or replace any tissue, organ or function of the body [1]. The success of biomaterials depends on several factors that determine their appropriate interaction with the host biological environment. Their physical and chemical properties, as well as topography and chemistry of the surface, have an important influence on cellular response [2]. In general, surfaces act as crucial platform in biology and medical fields since most of the biological reactions occur at the surface and interfaces [3]. In fact, the development of 
biomaterials requires detailed understanding on the interaction among the biomaterial surface, host tissue cells and extracellular matrix (ECM) to elicit ideal tissue response (Figure 1) [4].

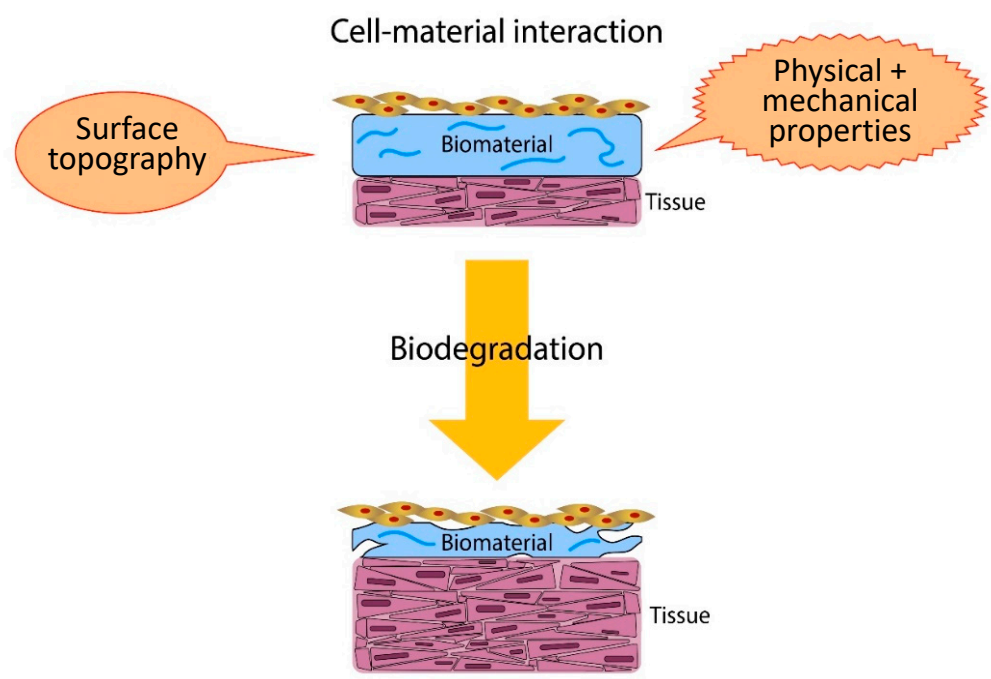

Figure 1. Schematic represents the crucial factors in tailoring a suitable biomaterial for tissue engineering.

An ideal biomaterial surface is necessary to stimulate a constructive cell response for wound reparation and tissue engineering, while unfavourable surface may indicate the material is to be explanted [5]. Biomaterial implanted in living organisms can trigger acute and chronic inflammatory responses [6]. Therefore, the right choice of material is crucial in tailoring biomaterial for tissue engineering. Among the various types of material, $\mathrm{P}(3 \mathrm{HB}-\mathrm{co}-4 \mathrm{HB})$ has gained attention for medical uses and regeneration medicine applications owing to its biocompatibility, chemical-diversity, biodegradability, non-genotoxicity and minimal tissue response in vivo [7]. Other biopolymers which have been widely used for biomaterials includes polyglycolic acid (PGA), poly(L-lactic acid) (PLLA) and poly(DL-lactic-co-glycolic acid) (PLGA), poly(l-lactic acid-co- $\varepsilon$-caprolactone) (PLCL) and polyurethane. However, the degradation of these biopolymers has proved to be a major drawback in medical applications. These biopolymers degrade acidic material and accumulate in the body. Thus, induces severe inflammatory responses, even causing cell and tissues necrosis [8].

However, the surface of $\mathrm{P}(3 \mathrm{HB}-c 0-4 \mathrm{HB})$ is hydrophobic with minimal recognition sites for cell attachment. As such, surface modifications are an effective approach in designing scaffolds in order to achieve biocompatibility properties in tissue engineering applications [8]. Surface modifications involve changes only at the outermost surface orientation and composition of biomaterial, without affecting its bulk properties [9]. Extensive research has been conducted to prepare various surfaces using several methods of surface modifications including biological modifications where natural polymer such as protein, polysaccharides, collagen and cellulose has been extensively utilized in tissue engineering applications. Among these, collagen has been widely used in various biomedical applications due to its abundance in the ECM, non-immunogenicity and various sources of existing isolation methods. Likewise, the collagen fibres also have some unique structural properties which play an important role in stimulating adjacent cells that regulate functional response and tissue engineering [10].

In addition, it has been shown that development of antimicrobial scaffolds is garnering interest for being able to prevent possible infections therefore, used as an alternative to control infection and minimize the use of antimicrobial agents. Thus, this work exhibits the modification of the surface of biodegradable $\mathrm{P}(3 \mathrm{HB}-\mathrm{co}-4 \mathrm{HB})$ combined with antimicrobial agent silver sulfadiazine (SSD) and collagen peptide in order to develop and design promising antimicrobial and biocompatible scaffolds for biomedical applications. The surface modification of the SSD blend/P(3HB-co-4HB) was done using a combination of surface functionalization methods which includes a combination of salt leaching and the freeze-drying technique. The porous surface of $\mathrm{P}(3 \mathrm{HB}-c \mathrm{-}-4 \mathrm{HB})$ was grafted with collagen 
peptide via aminolysis. Herein, the scaffolds were characterized by water contact angle, FTIR, SEM and subjected to cell proliferation assay using fibroblast cell L929. Increasing number of infections caused by pathogenic bacteria has severely affected human society these days. As such, the development of antimicrobial SSD blend/P(3HB-co-4HB)-collagen peptide is considered a significant reference for the construction of advanced biocompatible antibacterial biomaterials.

\section{Materials and Methods}

\subsection{Fabrication of Porous SSD Blend/P(3HB-co-4HB) Aminolysed Collagen Peptide Scaffolds}

The $\mathrm{P}(3 \mathrm{HB}-\mathrm{co}-95 \mathrm{~mol} \% 4 \mathrm{HB})$ copolymer was synthesized as previously described [11]. The extracted copolymer was used to fabricate porous $\mathrm{P}(3 \mathrm{HB}-\mathrm{co}-4 \mathrm{HB})$ scaffolds by employing salt leaching and freeze-drying method. Briefly, an amount of $0.83 \mathrm{~g}$ of $\mathrm{P}(3 \mathrm{HB}-c o-4 \mathrm{HB})$ was dissolved in chloroform with SSD $(4000 \mu \mathrm{g} / \mathrm{mL})$. The mixture was stirred vigorously. Then, sodium bicarbonate $\left(\mathrm{NaHCO}_{3}\right)$ which serves as porogen was added and stirred homogenously for $1 \mathrm{~h}$. The solution was cast in glass Petri dish (diameter of $9 \mathrm{~cm}$ ). The scaffolds were washed and the porogens were leached out. The scaffolds were further freeze-dried $(24 \mathrm{~h}$ ) and later vacuum-dried for $48 \mathrm{~h}$ using vacuum oven (BINDER $\mathrm{GmbH}$, Tuttlingen, Germany) to remove any remaining solvent. The scaffolds were rinsed with a large amount ( $200 \mathrm{~mL}$ ) of deionized water to remove any impurities. Then it is immersed in $10 \mathrm{wt} \%$ 1,6-hexanediamine/2-proponal solution at $37^{\circ} \mathrm{C}$ for $20 \mathrm{~min}$ [12], rinsed with deionized water for $24 \mathrm{~h}$ at room temperature to remove free 1,6-hexanediamine and finally dried in vacuum at $30^{\circ} \mathrm{C}$ for $24 \mathrm{~h}$ to constant weight. This $\mathrm{NH}_{2}-\mathrm{P}(3 \mathrm{HB}-\mathrm{co}-4 \mathrm{HB})$ scaffold was then immersed in $1 \mathrm{wt} \%$ GA solution for $3 \mathrm{~h}$ at room temperature, followed by rinsing with a large amount $(\sim 200 \mathrm{~mL})$ of deionized water for another $24 \mathrm{~h}$ to remove free GA. The scaffold was incubated in various concentrations of collagen peptide solution ( $\mathrm{pH} 3.4)$ for $24 \mathrm{~h}$ at $2-4{ }^{\circ} \mathrm{C}$. The collagen-P(3HB-co-4HB) membranes were rinsed with $1 \%$ acetic acid solution for $24 \mathrm{~h}$ to remove free collagen, followed by three washes with deionized water. The method of fabrication was summarized in Figure 2. The efficiency of collagen immobilization was determined as follows:

$$
\text { Collagen retain }=\left(\mathrm{W}_{\mathrm{c}}-\mathrm{W}_{\mathrm{b}}\right)-\left(\mathrm{W}_{\mathrm{c}}-\mathrm{W}_{\mathrm{o}}\right) / \mathrm{W}_{\mathrm{c}} \times 100 \%
$$

$\mathrm{W}_{\mathrm{o}}$ : Net weight scaffold without immobilisation of collagen peptide; $\mathrm{W}_{\mathrm{b}}$ : Net weight scaffold after immobilisation of collagen peptide; $\mathrm{W}_{\mathrm{c}}$ : Net weight scaffold without immobilisation of collagen peptide.

\subsection{Characterization of Porous SSD Blend/P(3HB-co-4HB)-Collagen Peptide}

The functional group of porous SSD Blend / $\mathrm{P}(3 \mathrm{HB}-\mathrm{co}-4 \mathrm{HB})$-collagen peptide was analysed using Fourier transform infrared (FTIR) spectroscopy analysis (Model RX1, PerkinElmer, UK). The spectra were recorded in transmittance mode and with the wavenumber range of $650-4000 \mathrm{~cm}^{-1}$ [13].

The surface morphology was observed by scanning electron microscopy SEM (Leo Supra 50 VP Field Mission SEM, Carl-Ziess SMT, Oberkochen, Germany). The samples were prepared by coating with gold to improve conductivity of the beam.

The water uptake ability of scaffolds was calculated based on the differences in the weight of the scaffolds. Basically, the scaffolds were cut into $1 \mathrm{~cm} \times 1 \mathrm{~cm}$ and dry weight before immersion $\left(\mathrm{m}_{\mathrm{o}}\right)$ and wet weight after immersion $\left(\mathrm{m}_{\mathrm{f}}\right)$ for $24 \mathrm{~h}$ and water uptake was calculated using the formula below:

$$
\text { Water uptake }=\left(\mathrm{m}_{\mathrm{o}}-\mathrm{m}_{\mathrm{f}}\right) / \mathrm{m}_{\mathrm{o}} \times 100 \%
$$

In order to determine the wettability properties, water contact angle of the scaffolds was conducted using sessile drop method (KSV CM200 Contact Angle, KSV CAM 200, KSV Instruments Ltd., Helsinki, Finland). The scaffolds were cut into $1 \mathrm{~cm} \times 1 \mathrm{~cm}$ pieces. The scaffolds were placed on the instrument and droplet of water was then deposited on the polymer surface by a specialized micro-syringe. The water droplet was observed from the computer screen and the contact angle was calculated. 
The pore size and porosity measurement of the scaffolds was calculated using Image Analyzer Software (Olympus Co. Ltd., Tokyo, Japan). The values of 100 different spots were analyzed and averaged [14].

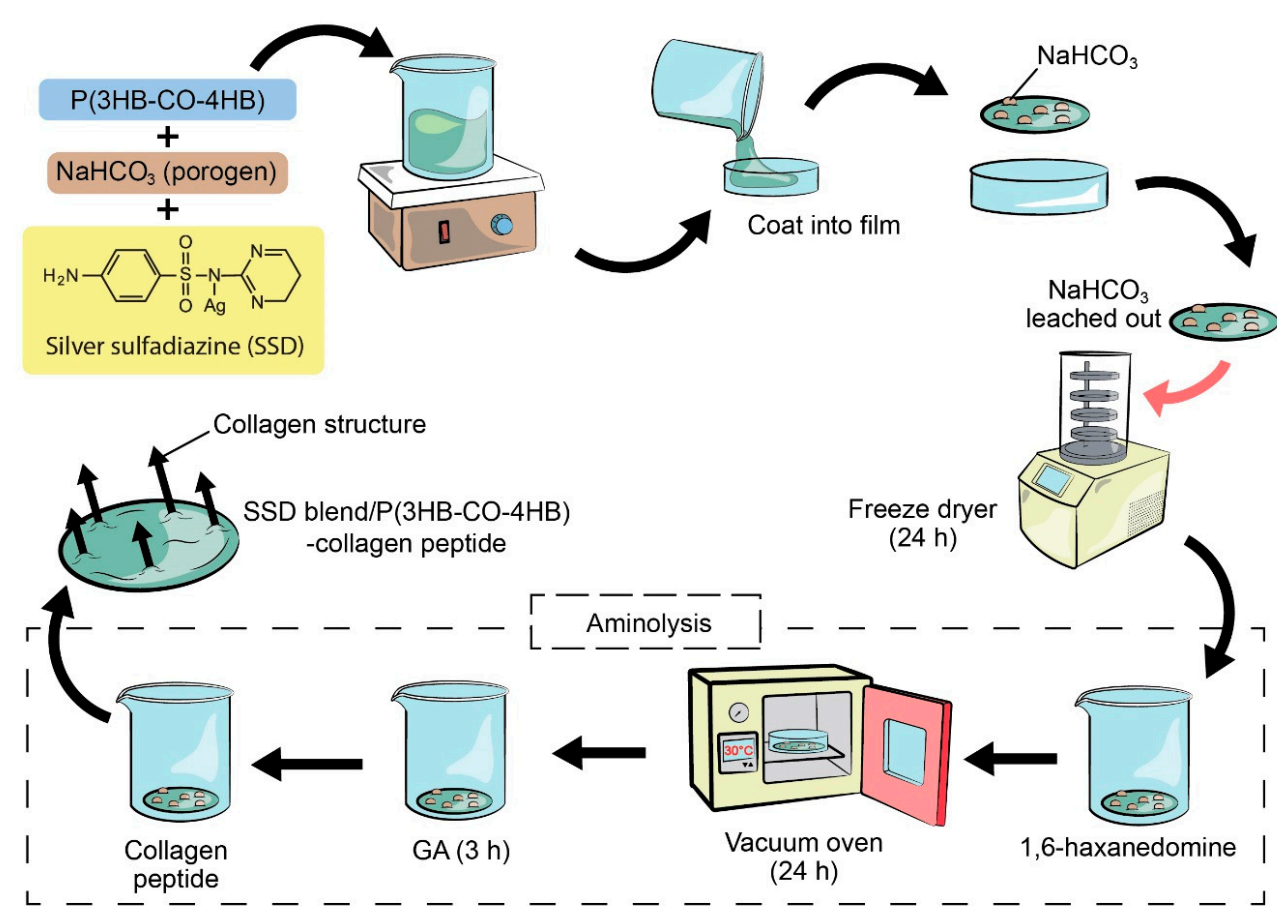

Figure 2. The summarised process of fabricating SSD blend/P(3HB-co-4HB)-collagen peptide.

\subsection{Antimicrobial Assay}

The antimicrobial activity assay was carried out using four opportunistic bacterial strains which includes Gram-positive [(Staphylococcus aureus (ATCC 12600)], Gram-negative [Pseudomonas aeruginosa (ATCC 17588)] and yeast Candida albicans was obtained from Microbiology Lab, School of Biological Sciences, Universiti Sains Malaysia. The bacterial suspension $(20 \mu \mathrm{L})$ with a total of $7.5 \times 10^{5} \mathrm{CFU} / \mathrm{mL}$ was added onto porous SSD blend $/ \mathrm{P}(3 \mathrm{HB}-c o-4 \mathrm{HB})$-collagen peptide. All the scaffolds the scaffolds were sterilized under UV (Spectrolinker ${ }^{\mathrm{TM}}$, XL-1000UV Cross linker, New York, NY, USA) at $1200 \mu \mathrm{J} / \mathrm{cm}^{2}$ for $30 \mathrm{~min}$ prior to testing. The scaffolds were incubated in the suspension at intervals of $0,6,12$, and $24 \mathrm{~h}$. At every interval, the suspension was spread on nutrient agar to observe the colonization of bacteria [15]. The percentages of inhibition were calculated using the following equation:

$$
\mathrm{C} \%=\left(\mathrm{C}_{\mathrm{o}}-\mathrm{C}_{\mathrm{e}}\right) / \mathrm{C}_{\mathrm{o}} \times 100 \%
$$

where $\mathrm{C} \%$ is percentage of inhibition, $\mathrm{C}_{\mathrm{e}}$ is $\mathrm{CFU}$ after incubation period, and $\mathrm{C}_{\mathrm{o}}$ is initial CFU before incubation period.

\subsection{Cell Proliferation Assay}

The proliferation of mouse fibroblast cell (L929, ATCC) on SSD blend /P(3HB-co-4HB)-collagen peptide was studied. The L929 cells were seeded on the scaffolds with a concentration of $2.5 \times 10^{4}$ cells/mL in Modified Eagle Medium (MEM) supplemented with $2 \mathrm{mM}$ L-glutamine, $1.5 \mathrm{~g} / \mathrm{L}$ sodium bicarbonate, $1 \mathrm{mM}$ of sodium pyruvate, $1000 \mathrm{U} / \mathrm{mL}$ penicillin-streptomycin and $10 \%(v / v)$ of bovine calf serum incubated at $37^{\circ} \mathrm{C}$ in $5 \%(v / v) \mathrm{CO}_{2}$ for 2-3 days. Prior to that the scaffolds were sterilized under UV (SpectrolinkerTM, XL-1000UV Cross linke, New York, NY, USA) at $1200 \mu \mathrm{J} / \mathrm{cm}^{2}$ for $30 \mathrm{~min}$ [12]. The cells viability and proliferation were assayed with MTS [3-(4,5-dimethylthiazol-2-yl)-5-(3carboxymethoxyphenyl)-2-(4-sulfophenyl)-2H-tetrazolium/PMS (phenazinmethosulfate) [16,17]. 


\subsection{Statistical Analysis}

All the data were analysed using ANOVA and Tukey's HSD test (SPSS 20 software, SPSS 20 software, IBM, New York, NY, USA) and expressed as mean \pm standard deviation (s.d.). The significance level of $p$-value $<0.05$ was considered significant.

\section{Results and Discussions}

\subsection{SSD Blend/P(3HB-co-4HB) Aminolysed Collagen Peptide}

The porous scaffold with impregnated SSD as antimicrobial properties was prepared using a combination of salt leaching and freeze-drying technique. As a matter of fact, the weight ratio of SSD to polymer is 1:500. The final content of the SSD is $6.3 \mu \mathrm{g}$ in the $1 \mathrm{~cm}^{2}$ scaffold. Subsequently, collagen peptide was immobilized onto the porous surface via aminolysis. The thickness of the scaffold was recorded at $626.0 \mu \mathrm{m} \pm 14$. Theoretically, salt-leaching is a simple technique where desirable pore sizes were created by flushing the porogen with water, leaving behind pores formed by the porogen [18]. With this aim in mind, $\mathrm{NaHCO}_{3}$ was used as porogen due to ease of removal since it is soluble in aqueous media. Furthermore, trapped $\mathrm{NaHCO}_{3}$ is not harmful to the human body owing to its function as a buffering agent in the human body [19]. Freeze-drying is another commonly used method to form porous or micro-rough surface on scaffolds. Apart from that, freeze-drying technique produces a uniform porous structure for potential scaffolds in tissue engineering applications. The inter-pore openings and pore shape of the scaffolds were fabricated through the salt-leaching technique that is known to be uncontrollable. Hence, combining salt-leaching with other techniques may enhance and improve the pore inter-connectivity and networking $[8,20]$.

The porosity of the developed SSD blend/P(3HB-co-4HB)-collagen peptide scaffolds were analysed through SEM technique as shown in Figure 3. The observation of SEM images exposed SSD blend/P(3HBco-4HB)-collagen peptide surface comprised open pores surface. The results show that the porosity of the varied collagen concentration of aminolysed scaffolds are almost similar which are in the range $38 \mu \mathrm{m}$ to $40 \mu \mathrm{m}$. The morphology of the surface revealed that, by combining salt-leaching and freeze-drying, a homogenous and interconnected macro-porous structure was produced.

Basically, the porous-based connectivity surface had enhanced the ECM architecture and provided a larger space to induce cell-material interactions [21,22].

As it is, aminolysis was carried out using 1,6-hexadiamine in 2-propanol; whereby the amino group of 1,6-hexadiamine reacts with carbonyl group of $\mathrm{P}(3 \mathrm{HB}-c o-4 \mathrm{HB})$. The $\mathrm{P}(3 \mathrm{HB}-c o-4 \mathrm{HB})-\mathrm{NH}_{2}$ scaffold was treated with gluteraldehyde (GA) in order to immobilize the collagen peptide onto the $\mathrm{P}(3 \mathrm{HB}-\mathrm{co}-4 \mathrm{HB})$ surface. The scaffolds were then immobilised using varied collagen concentrations $(2.5 \mathrm{wt} \%, 5 \mathrm{wt} \%, 7.5 \mathrm{wt} \%, 10 \mathrm{wt} \%, 12.5 \mathrm{wt} \%)$, respectively and this was verified using FTIR (Figure 4).

The FTIR was used to further confirm the immobilization of collagen peptide on to SSD blend/P(3HB-co-4HB) scaffolds. Based on the FTIR spectrums in Figure 4a, the collagen was identified based on the presence of amide I at $1630 \mathrm{~cm}^{-1}$, amide II band at $1531 \mathrm{~cm}^{-1}$. The conversion of primary amine to secondary amine by the formation of $\mathrm{C}=\mathrm{N}$ with the elimination of $-\mathrm{NH}_{2}$ was observed at $1647 \mathrm{~cm}^{-1}$ of aminolysed P(3HB-co-4HB)/collagen peptide scaffolds (Figure $4 \mathrm{~b}$ ). It also exhibited the absorption band at $1720 \mathrm{~cm}^{-1}$ present in the aminolysed $\mathrm{P}(3 \mathrm{HB}-\mathrm{co}-4 \mathrm{HB}) /$ collagen peptide scaffolds corresponds to the ester carbonyl group $(\mathrm{C}=\mathrm{O})$, being the main functional group of $\mathrm{P}(3 \mathrm{HB}-\mathrm{co}-4 \mathrm{HB})$. This finding has confirmed that the collagen was successfully immobilized to the $\mathrm{P}(3 \mathrm{HB}-\mathrm{co}-4 \mathrm{HB})$ scaffolds [13]. The FTIR spectrum was also used to characterize the molecular structure of SSD blended into the scaffolds. The absorption peak of at $3443 \mathrm{~cm}^{-1}$ corresponds to $-\mathrm{NH}_{2}$ symmetric of SSD. In contrast, the peak at $1545 \mathrm{~cm}^{-1}$ belongs to the phenyl skeletal vibration od SSD. The peak at $1228 \mathrm{~cm}^{-1}$ characterized the stretching vibration of $\left(\mathrm{SO}_{2}\right)$ group. This further emphasizes the presence of SSD blended into the aminolysed $\mathrm{P}(3 \mathrm{HB}-\mathrm{co}-4 \mathrm{HB}) /$ collagen peptide scaffolds $[23,24]$. 

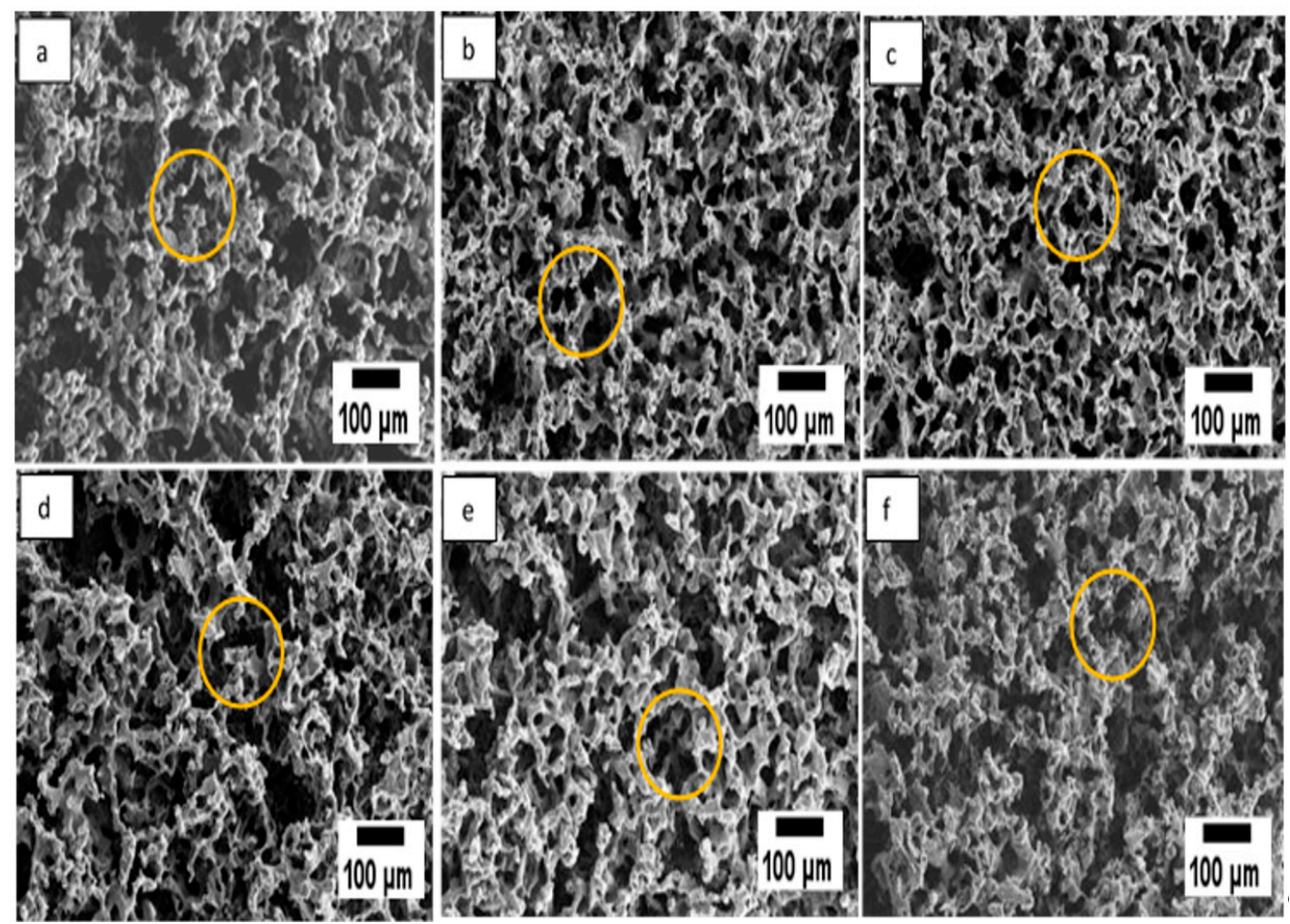

Figure 3. SEM micrographs of (a) $\mathrm{P}(3 \mathrm{HB}-c 0-4 \mathrm{HB})$, (b) $\mathrm{P}(3 \mathrm{HB}-c o-4 \mathrm{HB}) / 2.5 \mathrm{wt} \%$ collagen peptide, (c) $\mathrm{P}(3 \mathrm{HB}-c o-4 \mathrm{HB}) / 5 \mathrm{wt} \%$ collagen peptide, (d) $\mathrm{P}(3 \mathrm{HB}-c o-4 \mathrm{HB}) / 7.5 \mathrm{wt} \%$ collagen peptide, (e) $\mathrm{P}(3 \mathrm{HB}-c o-$ $4 \mathrm{HB}) / 10 \mathrm{wt} \%$ collagen peptide and (f) $\mathrm{P}(3 \mathrm{HB}-c o-4 \mathrm{HB}) / 12.5 \mathrm{wt} \%$ collagen peptide. The circles indicate the interconnected micro-pores.

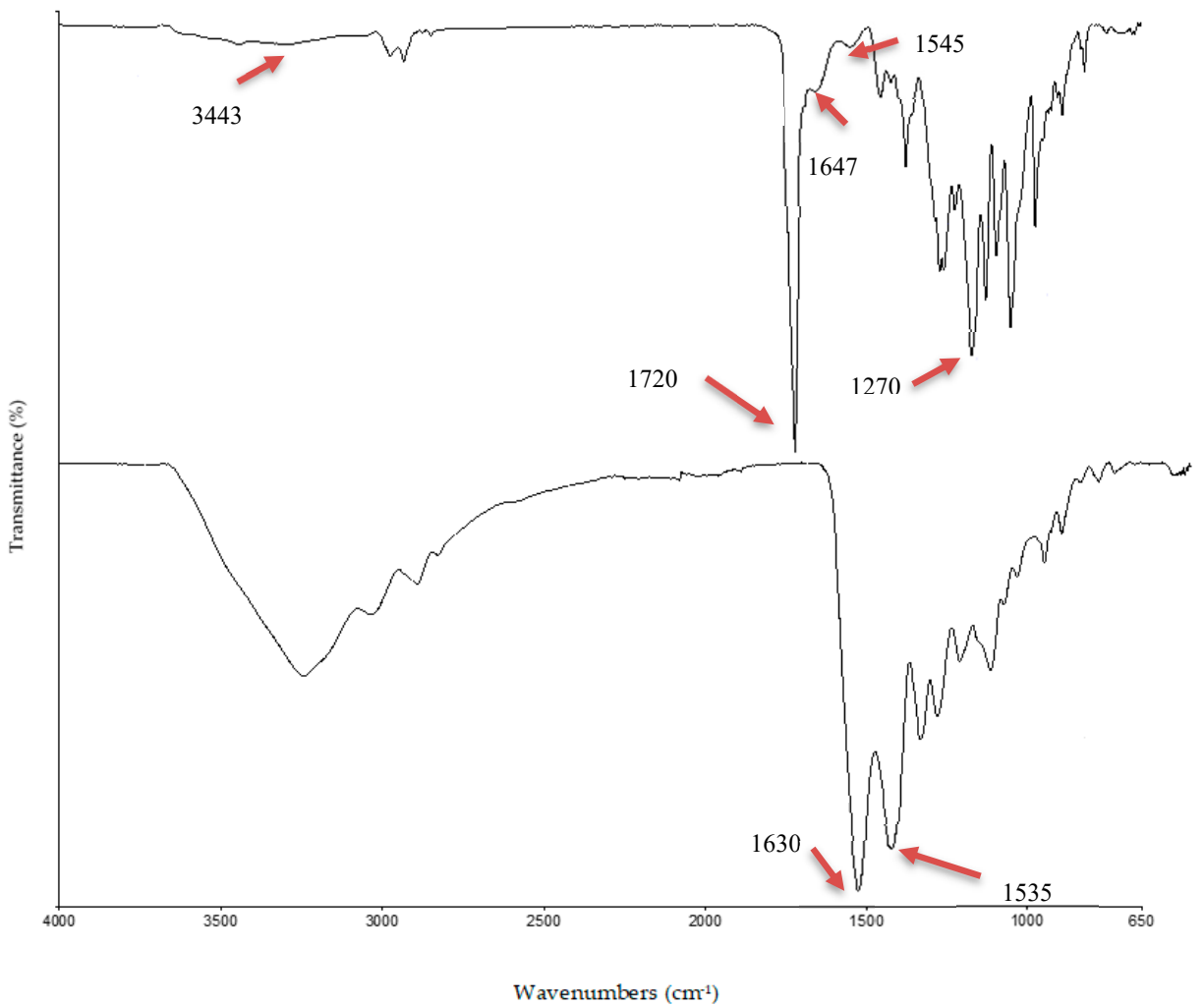

Figure 4. FTIR spectra of SSD blend/aminolysed $\mathrm{P}(3 \mathrm{HB}-\mathrm{co}-4 \mathrm{HB})$ scaffolds (a) collagen, (b) $\mathrm{P}(3 \mathrm{HB}-\mathrm{co}-$ $4 \mathrm{HB}) /$ collagen peptide. 
The actual amount of collagen peptides onto $\mathrm{P}(3 \mathrm{HB}-\mathrm{co}-4 \mathrm{HB})$ scaffolds were measured based on the weight of scaffolds. The amount of collagen immobilised onto SSD blend/collagen-peptide coated $\mathrm{P}(3 \mathrm{HB}-c o-4 \mathrm{HB})$ and SSD blend/collagen-peptide coated $\mathrm{P}(3 \mathrm{HB}-c o-4 \mathrm{HB})$ surface was manifested in Table 1. It can be deduced that the amount of collagen retained on the scaffolds was in the range of $78-85 \%$ without any significant difference among the scaffolds with different collagen concentration [13].

Table 1. The collagen peptide immobilisation efficiency based on the percentage of collagen reatined on the SSD blend/aminolysed $\mathrm{P}(3 \mathrm{HB}-\mathrm{co}-4 \mathrm{HB})$ scaffolds.

\begin{tabular}{cc}
\hline Polymer & Amount of Collagen Retained (\%) \\
\hline P(3HB-co-4HB $)+2.5 w t \%$ collagen & $78 \pm 2^{\mathrm{a}}$ \\
$\mathrm{P}(3 \mathrm{HB}-c o-4 \mathrm{HB})+5 w \mathrm{t} \%$ collagen & $80 \pm 3^{\mathrm{a}, \mathrm{b}}$ \\
$\mathrm{P}(3 \mathrm{HB}-c o-4 \mathrm{HB})+7.5 w \mathrm{t} \%$ collagen & $82 \pm 3^{\mathrm{a}, \mathrm{b}}$ \\
$\mathrm{P}(3 \mathrm{HB}-c o-4 \mathrm{HB})+10 w \mathrm{t} \%$ collagen & $83 \pm 2^{\mathrm{a}, \mathrm{b}}$ \\
$\mathrm{P}(3 \mathrm{HB}-c o-4 \mathrm{HB})+12.5 w \mathrm{w} \%$ collagen & $85 \pm 1^{\mathrm{b}}$ \\
\hline
\end{tabular}

Data represent means \pm SD $(n=3)$. Mean data accompanied by different alphabets $(a-b)$ indicates significant difference with each respective group (Tukey's HSD test, $p<0.05$ ).

\subsection{Hydrophilicity of SSD Blend/P(3HB-co-4HB)-Collagen Peptide Scaffold Wettability}

The hydrophilicity of SSD blend/P(3HB-co-4HB) aminolysed collagen peptide scaffold was determined using water contact angle analysis. Figure 5 presented the effects of water contact angle based on the interaction with various collagen peptide concentrations $(0,2.5,5,7.5,10,12.5 \mathrm{wt} \%)$. It can be deduced as the concentration of collagen peptide increased; the water contact angle of the scaffold decreased [13]. A four-fold of increase in hydrophilicity was observed from SSD blend/P(3HB-co-4HB) to the SSD blend/P(3HB-co-4HB) aminolysed $12.5 \mathrm{wt} \%$ collagen peptide. It is crucial to have an increased hydrophilic nature of biomaterial scaffolds surface as this can lead to improved cellular behaviors which includes cell adhesion, proliferation and differentiation. The improvement of SSD blend/P(3HB-co- $4 \mathrm{HB})$ aminolysed $12.5 \mathrm{wt} \%$ collagen peptide is comparable to nanofibers scaffolds of other biopolymers which includes PLGA, PLLA, PLCL and polyurethane as summarized in Table 2.

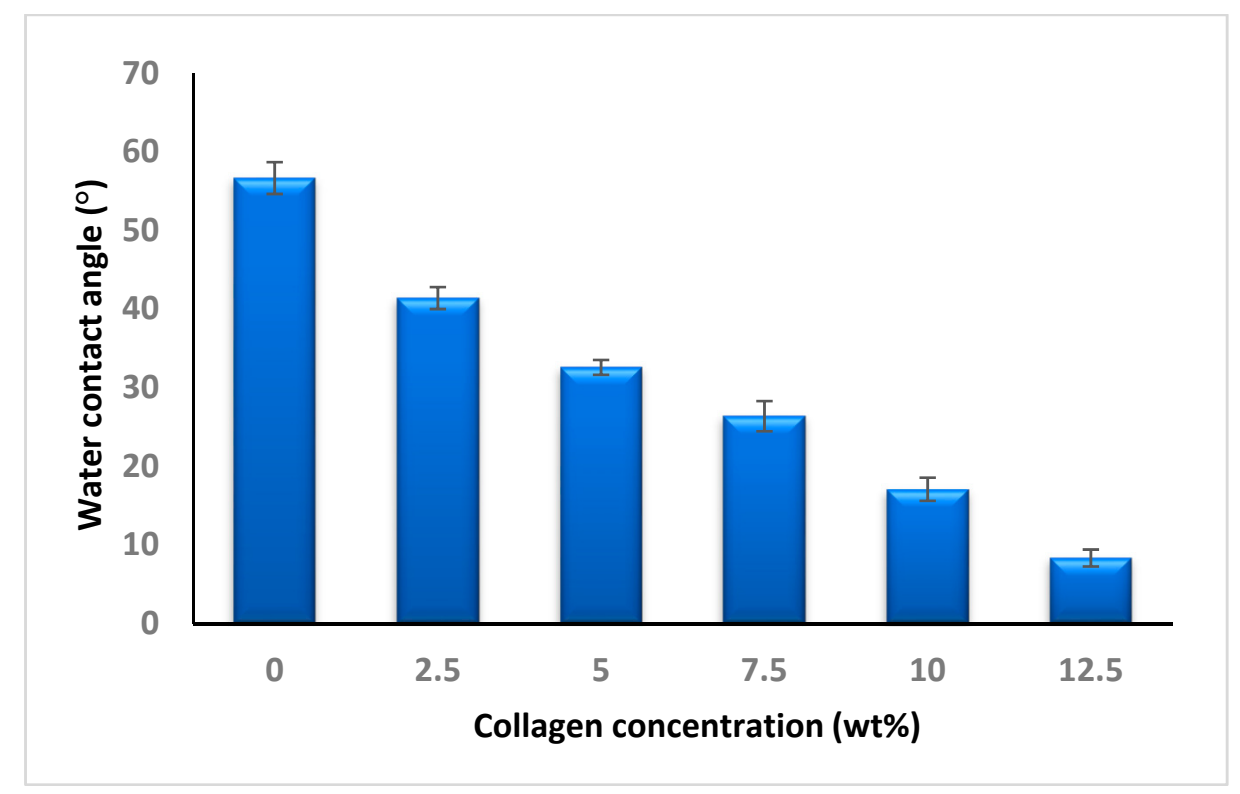

Figure 5. Water contact angle analysis of SSD blend/aminolysed $\mathrm{P}(3 \mathrm{HB}-\mathrm{co}-4 \mathrm{HB})$-collagen peptide scaffold. Data represent means \pm standard deviations $(n=3)$.

The water uptake ability analysis of the fabricated scaffolds was shown in Figure 6. Based on the results, the water uptake capacity increased as the concentration of immobilised collagen peptide in 
scaffold was increased [25]. The $\mathrm{P}(3 \mathrm{HB}-\mathrm{co}-4 \mathrm{HB})$ copolymer scaffolds recorded $111 \%$ of water absorption capacity, whereas the $\mathrm{P}(3 \mathrm{HB}-\mathrm{co}-4 \mathrm{HB})$-collagen peptide with collagen peptide concentration ranging 2.5 to $12.5 \mathrm{wt} \%$ recorded water uptake ability between $132 \%$ to $196 \%$ following an increasing trend. As a matter of fact, the two-fold increase in water absorption capacity due to the immobilization of collagen peptide developed a hydrophilic $\mathrm{P}(3 \mathrm{HB}-\mathrm{co}-4 \mathrm{HB})$ copolymer scaffold.

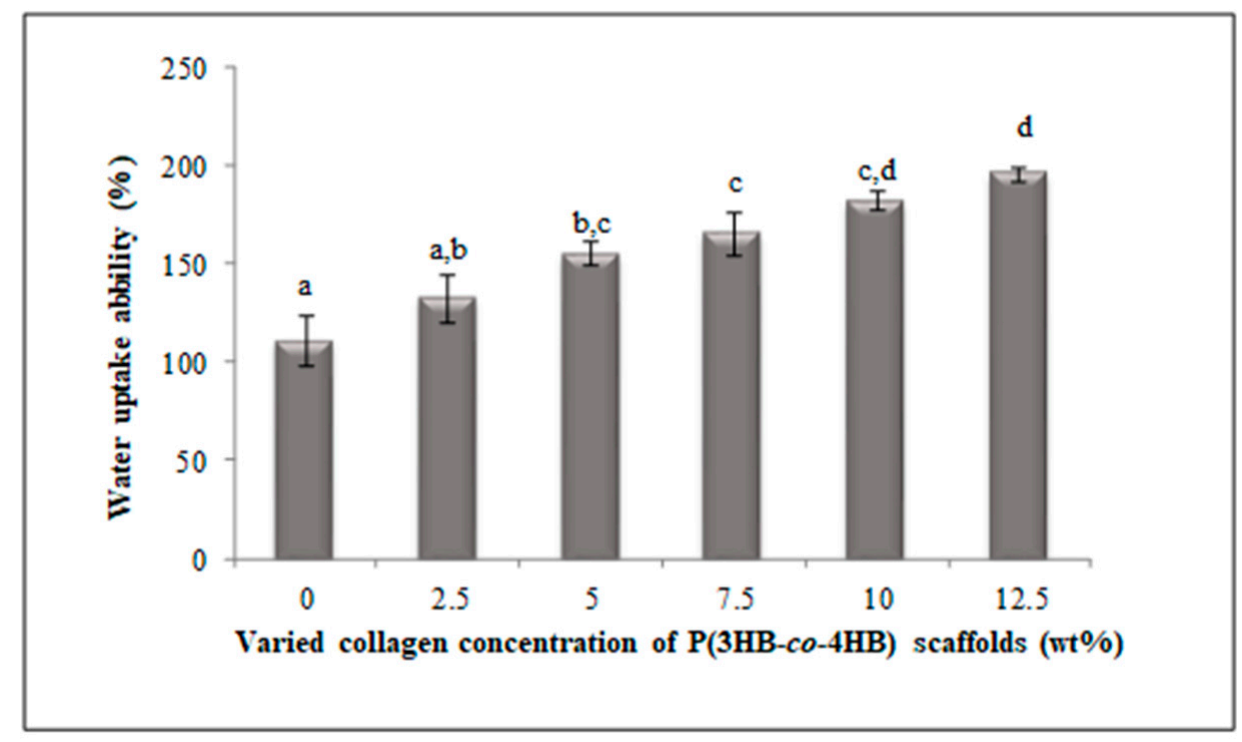

Figure 6. Water uptake ability of SSD blend/P(3HB-co-4HB) aminolysed collagen peptide scaffold. Data represent means $\pm S D(n=3)$. Mean data accompanied by different alphabets $(a-d)$ indicates significant difference with each respective group (Tukey's HSD test, $p<0.05$ ).

Table 2. Comparison of the water contact angle of biopolymer scaffolds widely used as biomaterials from previous studies with the developed SSD blend/ aminolysed $\mathrm{P}(3 \mathrm{HB}-\mathrm{co}-4 \mathrm{HB})$-collagen peptide scaffolds against various microorganisms.

\begin{tabular}{|c|c|c|}
\hline Biopolymer/Materials & Water Contact Angle Results & References \\
\hline PLGA/collagen nanofibers & $\begin{array}{l}\text { It is recorded that the contact angle of this electrospun } \\
\text { PLGA/collagen scaffold is } 70^{\circ} \text { and the addition of } \\
\text { collagen increased the wettability of the PLGA to be } \\
\text { developed as tissue engineering scaffolds for } \\
\text { regenerative medicine }\end{array}$ & [26] \\
\hline PLLA/collagen nanofibers & $\begin{array}{l}\text { The incorporation of collagen to the PLLA biopolymer } \\
\text { nanofibers to improve the surface wettability resulted } \\
\text { in a water contact angle of } 80^{\circ} \text { for the development of } \\
\text { bone graft. }\end{array}$ & [27] \\
\hline $\begin{array}{l}\text { Polyurethane/collagen by } \\
\text { green facile method }\end{array}$ & $\begin{array}{l}\text { The addition of collagen to the polyurethane exhibited } \\
\text { water contact angle between } 80-85^{\circ} \text { for the } \\
\text { development of smart materials that are } \\
\text { environmentally friendly and easier to process }\end{array}$ & [28] \\
\hline collagen/PLCL nanofibers & $\begin{array}{l}\text { The PLCL electrospun nanofiber with collagen had an } \\
\text { increased wettability between } 0^{\circ}(10 \mathrm{~s}) \text { and } 24^{\circ}(5 \mathrm{~s}) \text { for } \\
\text { the development of desirable scaffold for }\end{array}$ & [29] \\
\hline $\begin{array}{l}\mathrm{P}(3 \mathrm{HB}-c o-4 \mathrm{HB}) \text { aminolysed } \\
\text { collagen peptide }\end{array}$ & $\begin{array}{l}\text { The porous } \mathrm{P}(3 \mathrm{HB}-\mathrm{co}-4 \mathrm{HB}) \text { scaffolds incorporated with } \\
\text { collagen in this study showed an increased surface } \\
\text { wettability with water contact between } 4.3^{\circ} \pm 1.8^{\circ}- \\
43.7^{\circ} \pm 1.7^{\circ} \text { which can be further developed as tissue } \\
\text { regenerative scaffolds }\end{array}$ & Current paper \\
\hline
\end{tabular}


$\mathrm{P}(3 \mathrm{HB}-\mathrm{co}-4 \mathrm{HB})$ presents a hydrophobic nature, with poor hydrophilicity which is one of the limitations for biomedical application. Therefore, introducing collagen peptide via $-\mathrm{NH}_{2}$ groups using aminolysis was expected to introduce more hydrophilic contact points. Based on the results obtained, it can be observed that an increase in collagen peptide concentration up to $12.5 \mathrm{wt} \%$ resulted in an increase in surface wettability. Thus, indicating the increase of hydrophilicity at higher concentrations. Therefore, aminolysis was effective in modifying the hydrophilicity of $\mathrm{P}(3 \mathrm{HB}-\mathrm{co}-4 \mathrm{HB})$ surface $[24,25]$.

\subsection{Biocompatibility and Cell Proliferation of SSD Blend/P(3HB-co-4HB) Aminolysed Collagen Peptide Scaffolds}

The cellular behaviour or known as cell growth were assessed by seeding L929 fibroblasts cells onto the various aminolysed fabricated $\mathrm{P}(3 \mathrm{HB}-\mathrm{co}-4 \mathrm{HB})$ collagen peptide scaffolds. As illustrated in Figure 7 , the number of fibroblast cells found to have a stable growth on all the tested scaffolds over the time period of 3 days compared to the initial seeding. The fusion of collagen was able to improve the cytocompatibility. Surface modification via aminolysis has been commonly employed to enhance cell proliferation without property alteration $[12,30]$.

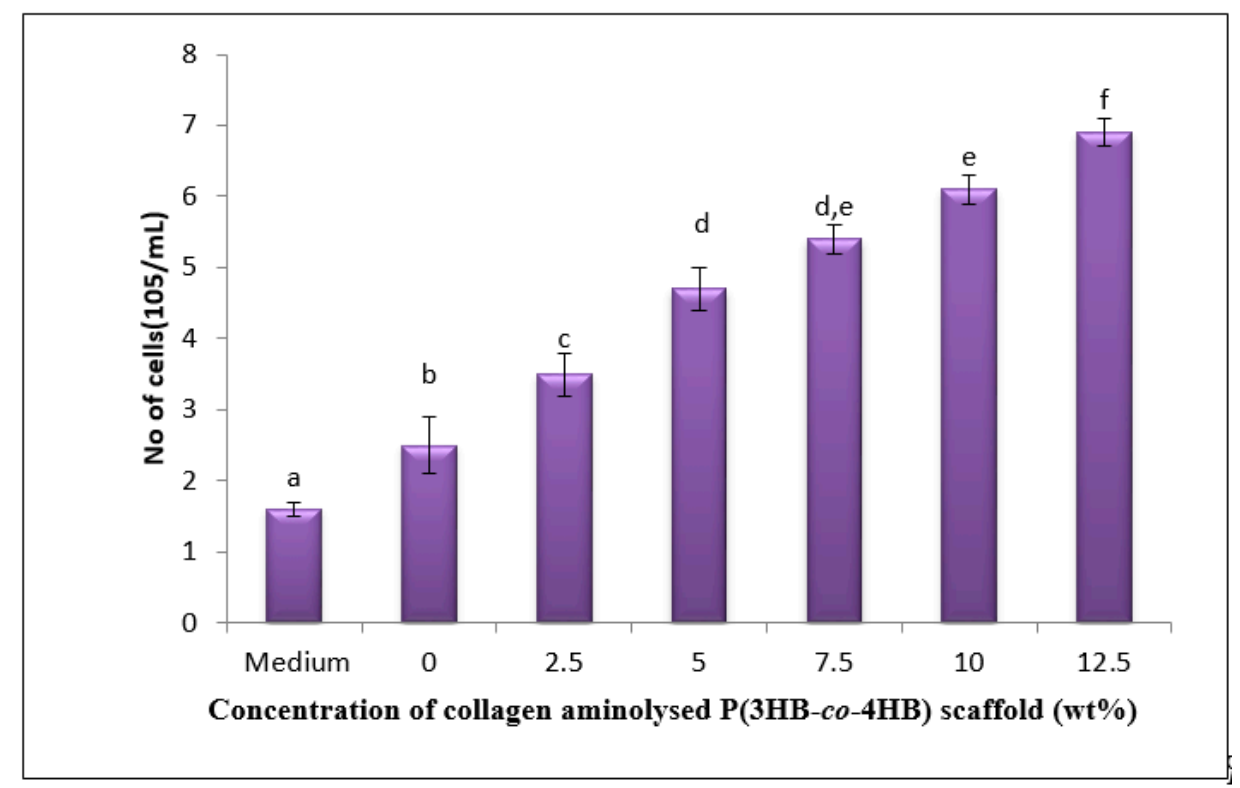

Figure 7. Proliferation of L929 cells on the various fabricated SSD blend/P(3HB-co-4HB) aminolysed collagen peptide scaffolds. Data represent means \pm SD $(n=5)$. Mean data accompanied by different alphabets (a-f) indicates significant difference with each respective group (Tukey's HSD test, $p<0.05$ ).

Concerning the increasing drift along the concentrations, the highest cell proliferation rate was acquired on scaffolds with $12.5 \mathrm{wt} \%$ collagen with cell count of $6.9 \times 10^{5}$ cells $/ \mathrm{mL}$. This is in accordance with highest water contact angle $\left(8.3^{\circ}\right)$ leading to better hydrophilicity of $\mathrm{P}(3 \mathrm{HB}-\mathrm{co}-4 \mathrm{HB})$ at $12.5 \mathrm{wt} \%$ collagen blend scaffolds. Improved wettability facilitates cell seeding on aminolysed scaffolds as a five-fold increase cell proliferation was observed in the the SSD blend/P(3HB-co-4HB) aminolysed $12.5 \mathrm{wt} \%$ collagen peptide [31].

On top of it, SEM analysis of $\mathrm{P}(3 \mathrm{HB}-\mathrm{co}-4 \mathrm{HB})$ scaffold (Figure 8), further supported the efficiency of $12.5 \mathrm{wt} \%$ collagen blend in terms of the surface morphology which happened to be rough and porous exhibiting the highest proliferation rate. The extracellular matrix (ECM) proteins, such as collagen peptides, adsorbed on to the scaffold surface when exposed to the physiological environment, allowing indirect fibroblast-scaffold interaction via the adsorbed ECM proteins. The cell-protein interaction of the scaffold is regulated by integrin, a cell membrane receptor [32]. The cellular activity criteria of SSD-blend/aminolysed P(3HB-co-4HB) scaffolds indicated their suitability for biomaterial applications. 

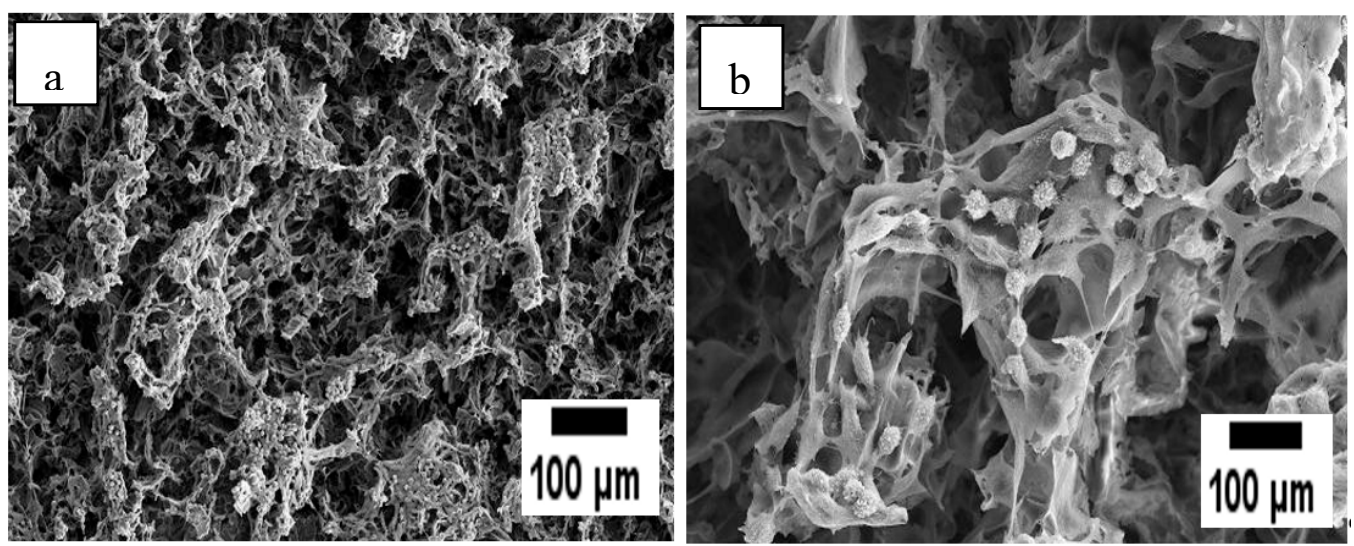

Figure 8. Proliferation of L929 cells on the SSD blend/P(3HB-co-4HB) scaffolds aminolysed $12.5 \mathrm{wt} \%$ collagen peptide. Magnification of $100 \times(\mathbf{a})$ and $503 \times(\mathbf{b})$ were used.

\subsection{Antimicrobial Analysis of Fabricated SSD Blend/P(3HB-co-4HB) Aminolysed Collagen Peptide Scaffold.}

The antimicrobial activity of the SSD blend/P(3HB-co-4HB)-collagen peptide against the microorganisms was quantitatively assayed through the colonization method. The data (Table 3) obtained from the colonization method revealed that the SSD exhibited good antimicrobial properties with variability in the inhibition rate against different tested strains. Meanwhile, the antimicrobial $\mathrm{P}(3 \mathrm{HB}-\mathrm{co}-4 \mathrm{HB})$ aminolysed collagen peptide scaffold showed susceptibility for Staphylococus auerus, Pseudomonas aeruginosa and Candida albicans at $24 \mathrm{~h}$ where their inhibition rate reached $100 \%$ at $48 \mathrm{~h}$. The results obtained exhibited that SSD showed varied inhibitory rates against the tested microorganisms. SSD impregnation aminolysed scaffolds are biocide-releasing polymers with prolonged release of SSD to efficiently kill microbes on contact. The sustained release of silver ions adheres to the microbial cell surface and causes membrane damage which enables the silver ions to penetrate inside the microbial cells and interact with cellular organelles and biomolecules, thereby, affecting respective cellular machinery causing cell death (Figure 9). Bacterial cells and yeast have a negative net charge at the surface due to their membrane proteins, as such the $\mathrm{Ag}+$ ion is attracted and able to disrupt the cytoplasmic membrane, thus causing cell lysis [33]. Herein, the incorporation of antimicrobial compounds onto polymer fibrous scaffolds with further antimicrobial properties release can be further improved as drug delivery system and regenerative medicine. The SSD blend/P(3HB-co-4HB)-collagen peptide has the potential of prolonged release of SSD, which provided an improved antimicrobial effect [34-36].

Table 3. Antimicrobial test of SSD blend/ aminolysed $\mathrm{P}(3 \mathrm{HB}-c 0-4 \mathrm{HB})$-collagen peptide scaffolds against various microorganisms.

\begin{tabular}{cccc}
\hline \multirow{2}{*}{ Time (h) } & \multicolumn{3}{c}{ Inhibition of Microorganisms (\%) } \\
\cline { 2 - 4 } & $\begin{array}{c}\text { Staphylococus auerus } \\
\text { ATCC 12600 }\end{array}$ & $\begin{array}{c}\text { Pseudomonas aeruginosa } \\
\text { ATCC 17588 }\end{array}$ & Candida albicans \\
\hline 0 & $0 \pm 0$ & $0 \pm 0$ & $0 \pm 0$ \\
6 & $24 \pm 5$ & $25 \pm 7$ & $32 \pm 2$ \\
12 & $45 \pm 3$ & $55 \pm 7$ & $61 \pm 8$ \\
24 & $65 \pm 9$ & $92 \pm 5$ & $82 \pm 8$ \\
48 & $100 \pm 0$ & $100 \pm 0$ & $100 \pm 0$ \\
\hline
\end{tabular}

Values are mean $\pm \mathrm{SD}$ of three replicates. 


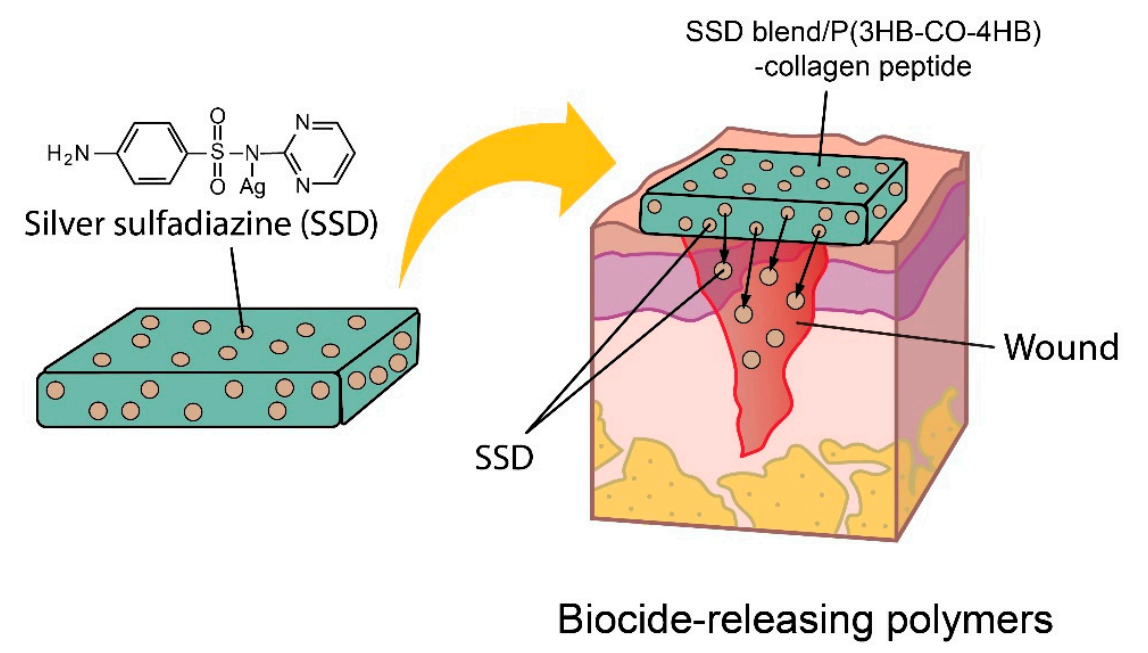

Figure 9. Schematic represents the SSD impregnation aminolysed scaffolds as biocide-releasing polymers with sustained release of SSD which efficiently kill microbes in contact.

\section{Conclusions}

The SSD-blend/P(3HB-co-4HB) aminolysed collagen peptide scaffold with porous surface was successfully developed. Collagen conjugation was done through the aminolysis technique where collagen peptide was covalently linked to $\mathrm{P}(3 \mathrm{HB}-\mathrm{co}-4 \mathrm{HB})$ scaffold. These $\mathrm{P}(3 \mathrm{HB}-\mathrm{co}-4 \mathrm{HB})$ scaffolds exhibited enhanced bioactivity of fibroblast cell (L929) growth and increased hydrophilicity with the presence of collagen peptides in the scaffold matrices. Scaffolds with physical modification effectively allow physical entrapping of therapeutic protein within a polymeric device. Thus, the immobilization of collagen provides a simple and convenient way to incorporate biological molecules onto polymer scaffolds, which makes this scaffold suitable for tissue engineering such as bone, cartilage, ligament, skin, vascular tissues, neural tissues, and skeletal muscle. Moreover, the main challenge in biomedical applications is developing scaffolds that promote tissue-cell interactions, such as adhesion and proliferation, while simultaneously inhibiting bacterial colonization. Therefore, the SSD-blend/P(3HB-co-4HB) aminolysed collagen peptide scaffold would be useful for bone, cartilage, and tissue regeneration with antimicrobial activity that can be released in a prolonged manner due to the presence of a reversible thermodynamic equilibrium between immobilized collagen and the incorporated antimicrobial agent.

Author Contributions: Conceptualization, S.V. and A.-A.A.A.; methodology, T.P.G.; software, T.P.G.; validation A.-A.A.A. and T.P.G.; formal analysis, T.P.G.; investigation, T.P.G.; resources, A.-A.A.A.; data curation, T.P.G. and S.V.; writing — original draft preparation, S.V.; writing—review and editing, S.V., and S.R.; visualization, S.R. and H.P.S.A.K.; supervision, A.-A.A.A.; project administration, T.P.G.; funding acquisition, A.-A.A.A. All authors have read and agreed to the published version of the manuscript.

Funding: This research was funded by The Fundamental Research Grant Scheme (FRGS), grant number 203/PBIOLOGI/6711602 provided by the Malaysian Ministry of Higher Education and is acknowledged for the financial support of this study.

Conflicts of Interest: The authors declare no conflict of interest. The funders had no role in the design of the study; in the collection, analyses, or interpretation of data; in the writing of the manuscript, or in the decision to publish the results.

\section{References}

1. Özkale, B.; Sakar, M.S.; Mooney, D.J. Active biomaterials for mechanobiology. Biomaterials 2020, $267,120497$. [CrossRef]

2. Rahmati, M.; Silva, E.; Reseland, J.E.; Heyward, C.A.; Haugen, H.J. Biological responses to physicochemical properties of biomaterial surface. Chem. Soc. Rev. 2020, 49, 5178-5224. [CrossRef] [PubMed] 
3. Gross, K.A.; Petzold, C.; Pluduma-LaFarge, L.; Kumermanis, M.; Haugen, H.J. Structural and Chemical Hierarchy in Hydroxyapatite Coatings. Materials 2020, 13, 4447. [CrossRef] [PubMed]

4. Aamodt, J.M.; Grainger, D.D. Extracellular matrix-based biomaterial scaffolds and the host response. Biomaterials 2016, 86, 68-82. [CrossRef]

5. Vladkova, T.G. Surface Engineered Polymeric Biomaterials with Improved Biocontact Properties. Int. J. Polym. Sci. 2010, 2010, 1-22. [CrossRef]

6. Chen, L.; Deng, H.; Cui, H.; Fang, J.; Zuo, Z.; Deng, J.; Li, Y.; Wang, X.; Zhao, L. Inflammatory responses and inflammation-associated diseases in organs. Oncotarget 2017, 9, 7204-7218. [CrossRef]

7. Vigneswari, S.; Chai, J.M.; Shantini, K.; Bhubalan, K.; Amirul, A.A. Designing Novel Interfaces via Surface Functionalization of Short-Chain-Length Polyhydroxyalkanoates. Adv. Polym. Technol. 2019, 2019, 1-15. [CrossRef]

8. Bhattarai, D.P.; Aguilar, L.E.; Park, C.H.; Kim, C.S. A Review on Properties of Natural and Synthetic Based Electrospun Fibrous Materials for Bone Tissue Engineering. Members 2018, 8, 62. [CrossRef]

9. Eltom, A.; Zhong, G.; Muhammad, A. Scaffold Techniques and Designs in Tissue Engineering Functions and Purposes: A Review. Adv. Mater. Sci. Eng. 2019, 2019, 1-13. [CrossRef]

10. Bose, S.; Robertson, S.F.; Bandyopadhyay, A. Surface modification of biomaterials and biomedical devices using additive manufacturing. Acta Biomater. 2018, 66, 6-22. [CrossRef]

11. Bonnans, C.; Chou, J.; Werb, Z. Remodelling the extracellular matrix in development and disease. Nat. Rev. Mol. Cell Biol. 2014, 15, 786-801. [CrossRef] [PubMed]

12. Huong, K.-H.; Teh, C.-H.; Amirul, A.A. Microbial-based synthesis of highly elastomeric biodegradable poly(3-hydroxybutyrate- co -4-hydroxybutyrate) thermoplastic. Int. J. Biol. Macromol. 2017, 101, 983-995. [CrossRef] [PubMed]

13. Vigneswari, S.; Chai, J.M.; Kamarudin, K.H.; Amirul, A.-A.A.; Focarete, M.L.; Ramakrishna, S. Elucidating the Surface Functionality of Biomimetic RGD Peptides Immobilized on Nano-P(3HB-co-4HB) for H9c2 Myoblast Cell Proliferation. Front. Bioeng. Biotechnol. 2020, 8, 567693. [CrossRef] [PubMed]

14. Vigneswari, S.; Murugaiyah, V.; Kaur, G.; bdul Khalil, H.P.; Amirul, A.A. Biomacromolecule immobilization: Grafting of fish-scale collagen peptides onto aminolyzed $\mathrm{P}(3 \mathrm{HB}-\mathrm{co}-4 \mathrm{HB})$ scaffolds as a potential wound dressing. Biomed. Mater. 2016, 11, 055009. [CrossRef] [PubMed]

15. Wang, Y.; Ke, Y.; Ren, L.; Wu, G.; Chen, X.; Zhao, Q. Surface engineering of PHBV by covalent collagen immobilization to improve cell compatibility. J. Biomed. Mater. Res. Part A 2008, 88, 616-627. [CrossRef]

16. Chai, C.; Amirul, A.; Vigneswari, S. Data on the effect of electrospinning parameters on the morphology of the nanofibrous poly(3-hydroxybutyrate-co-4-hydroxybutyrate) scaffolds. Data Brief 2020, 28, 104777. [CrossRef]

17. Ismail, I.; Gurusamy, T.P.; Ramachandran, H.; Amirul, A.A.-A. Enhanced production of poly(3-hydroxybutyrateco-4-hydroxybutyrate) copolymer and antimicrobial yellow pigmentation from Cupriavidus sp. USMAHM13 with antibiofilm capability. Prep. Biochem. Biotechnol. 2017, 47, 388-396. [CrossRef]

18. Vigneswari, S.; Khalil, H.P.S.A.; Amirul, A.A. Designing of Collagen Based Poly(3-hydroxybutyrate-co-4hydroxybutyrate) Scaffolds for Tissue Engineering. Int. J. Polym. Sci. 2015, 2015, 1-10. [CrossRef]

19. Liang, X.; Qi, Y.; Pan, Z.; He, Y.; Liu, X.; Cui, S.; Ding, J. Design and preparation of quasi-spherical salt particles as water-soluble porogens to fabricate hydrophobic porous scaffolds for tissue engineering and tissue regeneration. Mater. Chem. Front. 2018, 2, 1539-1553. [CrossRef]

20. Subia, B.; Kundu, J.; Kundu, C.S. Biomaterial Scaffold Fabrication Techniques for Potential Tissue Engineering Applications. Tissue Eng. 2010, 141. [CrossRef]

21. Siegler, J.C.; Midgley, A.W.; Polman, R.; Lever, R. Effects of Various Sodium Bicarbonate Loading Protocols on the Time-Dependent Extracellular Buffering Profile. J. Strength Cond. Res. 2010, 24, 2551-2557. [CrossRef] [PubMed]

22. Lutzweiler, G.; Halili, A.N.; Vrana, N.E. The Overview of Porous, Bioactive Scaffolds as Instructive Biomaterials for Tissue Regeneration and Their Clinical Translation. Pharmaceuticals 2020, 12, 602. [CrossRef] [PubMed]

23. Oikonomopoulos, I.; Perraki, T.; Tougiannidis, N. FTIR Study of Two Different Lignite Lithotypes From Neocene Achlada Lignite Deposits In Nw Greece. Bull. Geol. Soc. Greece 2017, 43, 2284-2293. [CrossRef]

24. El-Feky, G.S.; El-Banna, S.T.; El-Bahy, G.; Abdelrazek, E.; Kamal, M. Alginate coated chitosan nanogel for the controlled topical delivery of Silver sulfadiazine. Carbohydr. Polym. 2017, 177, 194-202. [CrossRef] 
25. Ratner, B.D. A pore way to heal and regenerate: 21st century thinking on biocompatibility. Regen. Biomater. 2016, 3, 107-110. [CrossRef]

26. Ahmed, M.; Ramos, T.A.D.S.; Damanik, F.; Le, B.Q.; Wieringa, P.; Bennink, M.L.; Van Blitterswijk, C.; De Boer, J.; Moroni, L. A combinatorial approach towards the design of nanofibrous scaffolds for chondrogenesis. Sci. Rep. 2015, 5, 14804. [CrossRef]

27. Zhou, G.; Liu, S.; Ma, Y.; Xu, W.; Meng, W.; Lin, X.; Wang, W.; Wang, S.; Zhang, J. Innovative biodegradable poly(L-lactide)/collagen/ hydroxyapatite composite fibrous scaffolds promote osteoblastic proliferation and differentiation. Int. J. Nanomed. 2017, 12, 7577-7588. [CrossRef]

28. Han, Y.; Jiang, Y.; Hu, J. Collagen incorporation into waterborne polyurethane improves breathability, mechanical property, and self-healing ability. Compos. Part A: Appl. Sci. Manuf. 2020, 133, 105854. [CrossRef]

29. Fu, W.; Liu, Z.; Feng, B.; Hu, R.; He, X.; Wang, H.; Yin, M.; Huang, H.; Zhang, H.; Wang, W. Electrospun gelatin/PCL and collagen/PLCL scaffolds for vascular tissue engineering. Int. J. Nanomed. 2014, 9, 2335-2344. [CrossRef]

30. Toledo, A.L.M.M.; Ramalho, B.S.; Picciani, P.H.S.; Baptista, L.; Martinez, A.M.B.; Dias, M.L. Effect of three different amines on the surface properties of electrospun polycaprolactone mats. Int. J. Polym. Mater. 2020, 1-13. [CrossRef]

31. Zhu, Y.; Gao, C.; Liu, X.; Shen, J. Surface Modification of Polycaprolactone Membrane via Aminolysis and Biomacromolecule Immobilization for Promoting Cytocompatibility of Human Endothelial Cells. Biomacromolecules 2002, 3, 1312-1319. [CrossRef] [PubMed]

32. Solouk, A.; Mirzadeh, H.; Shokrgozar, M.A.; Solati-Hashjin, M.; Najarian, S.; Seifalian, A.M. The Study of Collagen Immobilization on a Novel Nanocomposite to Enhance Cell Adhesion and Growth. Iran. Biomed. J. 2011, 15, 6-14. [PubMed]

33. Chen, Q.; Bruyneel, A.A.N.; Carr, C.; Czernuszka, J. Bio-mechanical Properties of Novel Bi-layer Collagen-Elastin Scaffolds for Heart Valve Tissue Engineering. Procedia Eng. 2013, 59, 247-254. [CrossRef]

34. Bazaka, K.; Jacob, M.V.; Crawford, R.J.; Ivanova, E.P. Efficient surface modification of biomaterial to prevent biofilm formation and the attachment of microorganisms. Appl. Microbiol. Biotechnol. 2012, 95, $299-311$. [CrossRef] [PubMed]

35. Bakare, R.A.; Bhan, C.; Raghavan, D. Synthesis and characterization of collagen grafted poly(hydroxybutyrateco-valerate) (PHBV) scaffold for loading of bovine serum albumin capped silver (Ag/BSA) nanoparticles in the potential use of tissue engineering application. Biomacromolecules 2014, 15, 423-435. [CrossRef]

36. Timofeeva, L.; Kleshcheva, N. Antimicrobial polymers: Mechanism of action, factors of activity, and applications. Appl. Microbiol. Biotechnol. 2011, 89, 475-492. [CrossRef]

Publisher's Note: MDPI stays neutral with regard to jurisdictional claims in published maps and institutional affiliations.

(C) 2020 by the authors. Licensee MDPI, Basel, Switzerland. This article is an open access article distributed under the terms and conditions of the Creative Commons Attribution (CC BY) license (http://creativecommons.org/licenses/by/4.0/). 